\title{
Effects of the protein phosphorylation inhibitor genistein on maturation of pig oocytes in vitro
}

\author{
T. Jung*, J. Fulka, Jr†, C. Lee and R. M. Moor \\ Department of Molecular Embryology, Institute of Animal Physiology and Genetics Research, \\ Babraham, Cambridge CB2 4AT, UK
}

\begin{abstract}
In vitro maturation of cumulus enclosed and denuded pig oocytes was reversibly inhibited by the protein kinase inhibitor genistein. The half-maximal effect on maturation was observed at $40 \mu \mathrm{g} \mathrm{ml}^{-1}$. Genistein inhibited total protein phosphorylation and synthesis with the same dose-response relationship $\left(\mathrm{ED}_{50}: 40 \mu \mathrm{g} \mathrm{ml}^{-1}\right)$. Protein phosphorylation and synthesis patterns were changed by effective concentrations of genistein. Pig oocytes were sensitive to genistein during the first $12 \mathrm{~h}$ of in vitro maturation. This genistein sensitive period corresponds closely with the period of sensitivity to the protein synthesis inhibitor cycloheximide. Whereas the inhibition of protein synthesis affects only nuclear membrane breakdown and not chromatin condensation, genistein inhibits both events. The results of these experiments suggest that protein phosphorylation and synthesis play major roles during pig oocyte maturation in vitro. It is concluded that genistein inhibited protein phosphorylation is a regulator of chromatin condensation, whereas both new protein synthesis and phosphorylation appear to be required for nuclear membrane disassembly. Caution about this second conclusion is, however, necessary because of the dual action of genistein on both protein phosphorylation and indirectly on protein synthesis.
\end{abstract}

\section{Introduction}

Protein phosphorylation and dephosphorylation play key roles in the regulation of meiotic maturation. The maturation-promoting factor (MPF) complex with its catalytic subunit p34 $4^{\text {ddc2 }}$, a serine and threonine protein kinase, is responsible for driving the meiotic and mitotic cell cycle from G2- to M-phase (Doree, 1990; Maller, 1990; Nurse, 1990; Norbury and Nurse, 1992). This MPF complex becomes activated by Thr 14 and Tyr 15 dephosphorylation and Thr161 phosphorylation of $\mathrm{p} 34^{\text {cdd } 2}$. In turn, the MPF activates its substrates. The best-qualified candidate substrates for $\mathrm{p} 34^{\text {cdd } 2}$ in animal cells are nuclear lamin, vimentin and caldesmon (reviewed by Norbury and Nurse, 1992). By an indirect pathway, microtubule-associated protein kinase (MAP kinase) becomes activated by phosphorylation on tyrosine (Ray and Sturgill, 1987, 1988; Gotoh et al., 1991). Meiotic maturation of animal oocytes therefore appears to involve not only dephosphorylation of $\mathrm{p} 34^{\text {cdc } 2}$ on threonine and tyrosine but also the phosphorylation of serine/threonine and tyrosine residues on other important regulatory molecules. Furthermore, mitogenic growth factors stimulate cell proliferation by pathways involving serine/threonine or tyrosine phosphorylation or both (Yarden and Ullrich, 1988).

We report here the effects of the protein kinase inhibitor genistein on pig oocyte maturation. Genistein, which is an iso-

*Present address: BfS Institute of Radiation Hygiene, Ingolstaedter Landstrasse 1, D-85764 Oberschleissheim, Germany.

†Permanent address: Institute of Animal Production, CR-104 00 Prague 10, Czech Republic.

Received 14 September 1992. flavone, inhibits tyrosine protein kinase and protein kinase $\mathrm{C}$ activity and to a lesser extent other protein kinases (Akiyama et al., 1987; Geissler et al., 1990). Genistein reversibly inhibited maturation of pig oocytes, but with a genistein sensitive period during the first $12 \mathrm{~h}$ of maturation only. However, the effective concentration of genistein also influenced overall protein phosphorylation and protein synthesis.

\section{Materials and Methods}

\section{Collection and culture of oocytes}

Pig ovaries were collected from a local abattoir and transported to the laboratory in a thermo-container within $30 \mathrm{~min}$. Oocytes were aspirated from large antral follicles $(3-5 \mathrm{~mm})$ and only fully grown oocytes surrounded by a compact cumulus were used. Cumulus-enclosed oocytes were mechanically denuded to provide oocytes free of somatic cells (denuded oocytes). Aspiration, selection and culture were performed in medium 199 (Morton, 1970) supplemented with sodium pyruvate $\left(100 \mu \mathrm{g} \mathrm{ml}^{-1}\right)$, gentamycin $\left(25 \mu \mathrm{g} \mathrm{ml}^{-1}\right), \mathrm{BSA}\left(10 \mathrm{mg} \mathrm{ml}^{-1}\right)$ and Pergonal ( $0.1 \mathrm{iu} \mathrm{ml}^{-1}$, Serono, Welwyn Garden City). Culture was performed in vitro at $38.5^{\circ} \mathrm{C}$ in $5 \% \mathrm{CO}_{2}$ in air. The activities of tyrosine kinases were inhibited by the addition of genistein (MW 270.2; Sigma, Poole) to final concentrations of $0,20,40,60$ or $80 \mu \mathrm{g} \mathrm{ml}^{-1}\left(74,148,222\right.$ or $296 \mu \mathrm{mol} \mathrm{I}^{-1}$, respectively). Genistein was dissolved in dimethyl sulfoxide (DMSO) and all cultures were adjusted to the same DMSO concentration $\left(1 \mu \mathrm{g} \mathrm{ml}^{-1}\right)$. 
Table 1. Effects of genistein on cumulus-enclosed pig oocytes after $24 \mathrm{~h}$ in vitro

\begin{tabular}{|c|c|c|c|c|c|c|c|c|c|c|}
\hline \multirow{3}{*}{$\begin{array}{l}\text { Morphology } \\
\text { GV I }\end{array}$} & \multicolumn{10}{|c|}{ Concentration of genistein $\left[\mu \mathrm{g} \mathrm{ml}^{-1}\right]$} \\
\hline & \multicolumn{2}{|c|}{0} & \multicolumn{2}{|c|}{20} & \multicolumn{2}{|c|}{40} & \multicolumn{2}{|c|}{60} & \multicolumn{2}{|c|}{80} \\
\hline & $2^{\mathrm{a}}$ & $1 \%$ & 1 & $2 \%$ & 5 & $7 \%$ & 119 & $64 \%$ & 201 & $90 \%$ \\
\hline GV II & 10 & $7 \%$ & & & 5 & $7 \%$ & 10 & $5 \%$ & 20 & $9 \%$ \\
\hline GV III & 4 & $3 \%$ & & & 10 & $13 \%$ & 31 & $17 \%$ & & \\
\hline GV IV & 6 & $4 \%$ & & & 5 & $7 \%$ & 20 & $11 \%$ & & \\
\hline LD-MI & 110 & $77 \%$ & 57 & $98 \%$ & 50 & $67 \%$ & 7 & $4 \%$ & 3 & $1 \%$ \\
\hline AI-MII & 10 & $7 \%$ & & & & & & & & \\
\hline \multicolumn{11}{|l|}{ Number of } \\
\hline oocytes & 142 & & 58 & & 75 & & 187 & & 224 & \\
\hline
\end{tabular}

GV I-GV IV: germinal vesicle I-IV stage according to Motlik and Fulka (1976); LD-MI: Late diakinesis-metaphase I stage AI-MII Anaphase I-metaphase II stage.

aalues are absolute numbers (Ist column) and relative numbers of oocytes (as \% of total; 2nd column).

\section{Radiolabelling of oocyte proteins}

Protein synthesis was studied by incubating cumulusenclosed pig oocytes for $2 \mathrm{~h}$ in $\left[{ }^{35} \mathrm{~S}\right.$ - $m$ methionine ( $T$ ran ${ }^{35} \mathrm{~S}$-label, specific activity $>37 \mathrm{TBq} \mathrm{mmol}^{-1}$, ICN, High Wycombe) at an isotope concentration of $37 \mathrm{MBq} \mathrm{ml}^{-1}$ using phosphatefree, Hepes-buffered M2 medium. Protein phosphorylation was studied by labelling oocytes for $2 \mathrm{~h}$ in $\left[{ }^{32} \mathrm{P}\right]$ orthophosphate (carrier-free, ICN) at an isotope concentration of $37 \mathrm{MBq} \mathrm{ml} \mathrm{m}^{-1}$ using phosphate-free, Hepes-buffered M2 medium. All labelled oocytes were denuded of cumulus cells before collection for electrophoresis. Labelling of the inhibitortreated oocytes was performed in the presence of $0,20,40$ or $60 \mu \mathrm{g}$ genistein $\mathrm{ml}^{-1}$.

\section{Assessment of oocyte maturation}

The effects of genistein on in vitro maturation of cumulusenclosed or denuded pig oocytes were determined using the whole mount procedure with fixation in ethanol:acetic acid $(3: 1 \mathrm{v} / \mathrm{v})$ and staining with orcein.

\section{Gel electrophoresis}

Samples were collected in $2 \mu \mathrm{l}$ phosphate-buffered saline and lysed with $15 \mu \mathrm{l}$ of $2 \times$-concentrated SDS-sample buffer. An aliquot of $2 \mu \mathrm{l}$ was removed for measuring the incorporation of label into TCA-precipitable material. One-dimensional electrophoresis was performed on $8-15 \%$ linear gradient SDS polyacrylamide gels (Laemmli, 1970). Equal amounts of TCAprecipitable radioactive samples were added to each lane of the gels to facilitate direct comparisons. Direct autoradiography was carried out on dried gels using Hyperfilm $\beta$-max (Amersham).

\section{Results}

Pig oocytes aspirated from large antral follicles and cultured in vitro underwent germinal vesicle breakdown after about $24 \mathrm{~h}$. The ensuing metaphase I stage then persisted for about $8 \mathrm{~h}$. The timing of the maturation cycle of individual oocytes, however, varies by about 3-4 $\mathrm{h}$ from the median outlined above. Freshly collected oocytes fixed at aspiration $(n=125)$ and characterized using the criteria of Motlik and Fulka (1976) were predominantly at the GV I stage (germinal vesicle I stage, $81 \%$ ) with $16 \%$ at GV II and to $3 \%$ in LD-MI stage (late diakinesis metaphase I stage) of nuclear development at the time of collection.

\section{Effects of genistein on germinal vesicle breakdown}

Cumulus-enclosed pig oocytes were matured in vitro for $24 \mathrm{~h}$ in the presence of increasing concentrations of genistein (Table 1). Treatment decreased the proportion of oocytes undergoing maturation in a dose-dependent manner from 0 to $80 \mu \mathrm{g}$ genistein $\mathrm{ml}^{-1}$ as assessed after $24 \mathrm{~h}\left(\mathrm{ED}_{50}: 40 \mu \mathrm{g} \mathrm{ml}^{-1}\right)$. The highest concentration of genistein used resulted in total inhibition of maturation. Genistein blocked both chromatin condensation (progression from GV I to GV IV stage) and nuclear membrane breakdown. Similar experiments were performed with denuded pig oocytes. A high concentration of genistein $\left(80 \mu \mathrm{g} \mathrm{ml}^{-1}\right)$ totally blocked oocyte maturation in vitro (data not shown).

\section{Critical time for the genistein action during pig oocyte maturation}

Cumulus-enclosed pig oocytes were matured in vitro for a total of $24 \mathrm{~h}$. They were first cultured for 6,12 or $16 \mathrm{~h}$ in genistein-free medium and then transferred to medium containing genistein $\left(80 \mu \mathrm{g} \mathrm{ml}^{-1}\right)$ for 18,12 or $8 \mathrm{~h}$, respectively (Table 2 ). Oocytes cultured for 6 or $12 \mathrm{~h}$ in control medium and then transferred into genistein medium were blocked from further development. In these two groups meiotic progression was immediately blocked by the addition of genistein. By delaying the addition of genistein until the final $8 \mathrm{~h}$ of culture $(16-24 \mathrm{~h})$, no meiotic arrest was detected and the pig oocytes progressed normally to metaphase I. 
Table 2. Time course of genistein sensitivity during maturation of cumulus-enclosed pig oocytes in vitro

Time in control medium plus

time in genistein ${ }^{\mathrm{a}}$ medium
$6 \mathrm{~h}$
$6 \mathrm{~h}+18 \mathrm{~h}$

$12 \mathrm{~h}$

$12 h+12 h$

$16 \mathrm{~h}$

$16 \mathrm{~h}+8 \mathrm{~h}$

\begin{tabular}{|c|c|c|c|c|c|c|c|c|c|c|c|c|}
\hline GV I & $33^{b}$ & $66 \%$ & 48 & $42 \%$ & 10 & $13 \%$ & 15 & $15 \%$ & 5 & $5 \%$ & 1 & $1 \%$ \\
\hline GV II & 15 & $30 \%$ & 49 & $43 \%$ & 28 & $35 \%$ & 27 & $27 \%$ & 20 & $20 \%$ & & \\
\hline GV III & & & 10 & $9 \%$ & 26 & $33 \%$ & 35 & $35 \%$ & 32 & $32 \%$ & 5 & $5 \%$ \\
\hline GV IV & & & & & 5 & $6 \%$ & 14 & $14 \%$ & 30 & $30 \%$ & 18 & $18 \%$ \\
\hline Number of oocytes & 50 & & 113 & & 79 & & 101 & & 101 & & 99 & \\
\hline
\end{tabular}

"Concentration of genistein: $80 \mu \mathrm{g} \mathrm{ml}$ '.

'Values are absolute numbers (1st column) and relative numbers of oocytes (in \% of total; 2nd column).

GV I-GV IV: Germinal vesicle I-IV stage according to Motlik and Fulke (1976); LD-MI: late diakinesis-metaphase I stage.

Table 3. Effects of genistein on cumulus-enclosed pig oocytes after $24 \mathrm{~h}$ in vitro: incorporation of $\left[{ }^{32} \mathrm{P}\right]$ orthophosphate or $\left[{ }^{35} \mathrm{~S}\right] \mathrm{methionine}$ into oocyte proteins

\begin{tabular}{|c|c|c|c|c|c|c|c|c|}
\hline \multirow{2}{*}{$\begin{array}{l}\text { Genistein } \\
\text { concentration } \\
{\left[\mu \mathrm{g} \mathrm{ml}^{-1}\right]}\end{array}$} & \multicolumn{4}{|c|}{$\begin{array}{c}{ }^{32} \mathrm{P} \text { incorporation } \\
\text { (c.p.m. in } 2 \mathrm{~h} \text { per oocyte) }\end{array}$} & \multicolumn{4}{|c|}{$\begin{array}{c}{ }^{35} \mathrm{~S} \text { incorporation } \\
\text { (c.p.m. in } 2 \mathrm{~h} \text { per oocyte) }\end{array}$} \\
\hline & $\bar{x}$ & SEM & $n$ & $\%$ & $\bar{x}$ & SEM & $n$ & $\%$ \\
\hline 0 & 12855 & 1221 & 47 & 100 & 10710 & 1017 & 28 & 100 \\
\hline 20 & 12858 & 1350 & 30 & 100 & 11540 & 1039 & 30 & 108 \\
\hline 40 & 4267 & 363 & 30 & 33 & 3940 & 433 & 30 & 37 \\
\hline 60 & I 557 & 156 & 30 & 12 & 1560 & 187 & 30 & 15 \\
\hline 80 & 205 & 27 & 93 & 2 & 274 & 49 & 13 & 3 \\
\hline
\end{tabular}

\section{Reversibility of genistein effects}

Cumulus-enclosed pig oocytes were cultured in vitro for $24 \mathrm{~h}$ in the presence of $80 \mu \mathrm{g}$ genistein $\mathrm{ml}^{-1}$. They were then cultured for a further $24 \mathrm{~h}$ in genistein-free medium. After this pulse-chase treatment $210(80 \%)$ oocytes reached LD-MI stage and 40 (15\%) developed to MII (metaphase II) stage. In total, 264 oocytes were analysed, and the remaining $14(5 \%)$ arrested at the GV stage. We therefore conclude that the effects of genistein on meiotic progression to metaphase I were fully reversible. However, further maturation to MII was retarded compared with control oocytes.

\section{Effects of genistein on protein synthesis and protein phosphorylation of pig oocytes matured in vitro}

Cumulus-enclosed pig oocytes were matured in vitro for $24 \mathrm{~h}$ in the presence of $0,20,40,60$ or $80 \mu \mathrm{g}$ genistein $\mathrm{ml}^{-1}$. They were labelled during the last $2 \mathrm{~h}$ of culture with $\left[{ }^{35} \mathrm{~S}\right]$ methionine or ${ }^{32} \mathrm{P}$ lorthophosphate in the presence of genistein. Trichloroacetic acid precipitable incorporation was measured by measurement of radioactivity in a $\beta$-scintillation counter (Table 3 ). Concentrations of $20 \mu \mathrm{g}$ genistein $\mathrm{ml}^{-1}$ and higher decreased $\left[{ }^{35} \mathrm{~S}\right]$ methionine and $\left.{ }^{32} \mathrm{P}\right]$ orthophosphate incorporation in a comparable dose-dependent manner $\left(\mathrm{ED}_{50}: 40 \mu \mathrm{g} \mathrm{ml}^{-1}\right)$. At a concentration of $80 \mu \mathrm{g}$ genistein $\mathrm{ml}^{-1}$ protein synthesis and protein phosphorylation were reduced to 3 and $2 \%$ of control levels, respectively.

After treatment with $0,20,40$ or $60 \mu \mathrm{g}$ genistein $\mathrm{ml}^{-1},\left[{ }^{35} \mathrm{~S}\right]$ or $\left[{ }^{32} \mathrm{P}\right]$-labelled oocyte proteins were separated by SDS polyacrylamide gel electrophoresis. Protein synthesis patterns were changed in a progressive manner by increasing concentrations of genistein (Fig. 1). After treatment with $20 \mu \mathrm{g}$ genistein $\mathrm{ml}^{-1}$ the protein pattern was very similar to that of control oocytes; however, the intensity of the two proteins at 66 and $28 \mathrm{kDa}$ was less. Treatment with 40 and $60 \mu \mathrm{g}$ genistein ml ${ }^{-1}$ changed the normal protein pattern significantly. The most significant changes were observed as a decrease at 180-170, 95, 85, 66, 35, $32,28,25-23$ and $19 \mathrm{kDa}$ and a relative increase at 60 and $40 \mathrm{kDa}$. The protein synthesis patterns after treatment with 40 or $60 \mu \mathrm{g}$ genistein $\mathrm{ml}^{-1}$ were significantly different from those of GV control oocytes (T. Jung, J. Fulka, Jr and R. M. Moor, unpublished).

Protein phosphorylation patterns were changed by genistein in a similar manner to those for new protein synthesis (Fig. 2). After treatment with $20 \mu \mathrm{g}$ genistein $\mathrm{ml}^{-1}$, phosphorylation was unchanged. A further increase of the genistein concentration led to a decrease of phosphorylation at 100,66, 50,29, 23 and $20 \mathrm{kDa}$ and to a relative increase in phosphorylation at $55,48,40,28,26$ and $22 \mathrm{kDa}$. The phosphorylation patterns 


\section{Genistein}

\section{$0 \quad 20 \quad 40 \quad 60$}
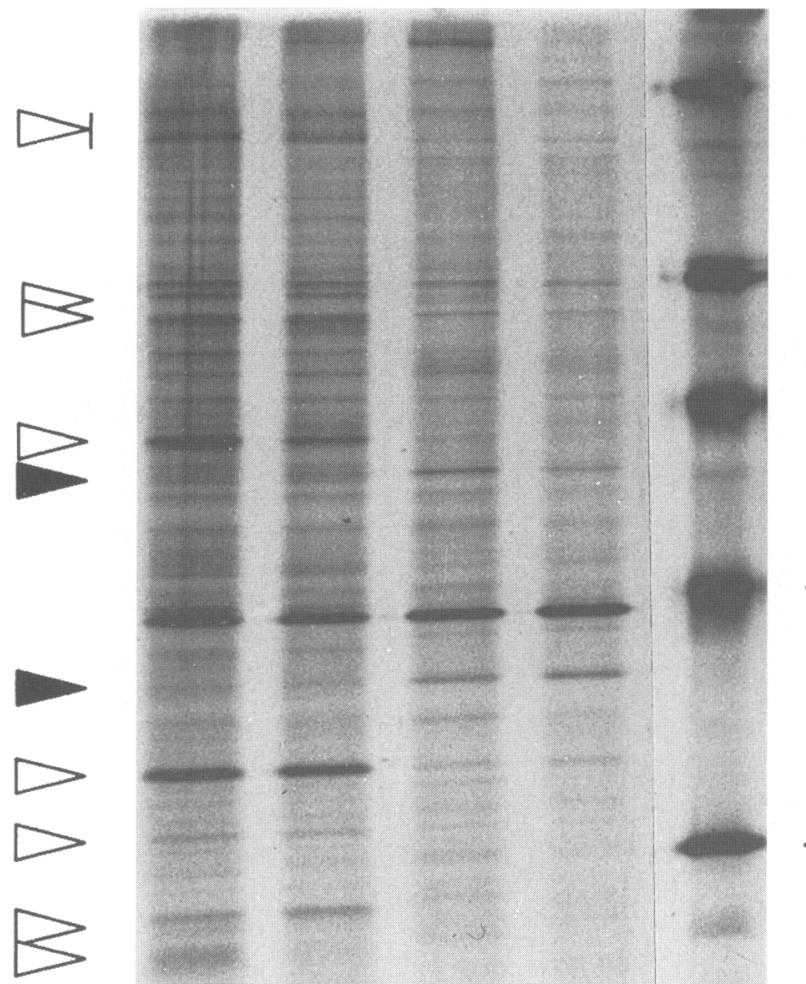

$-200$
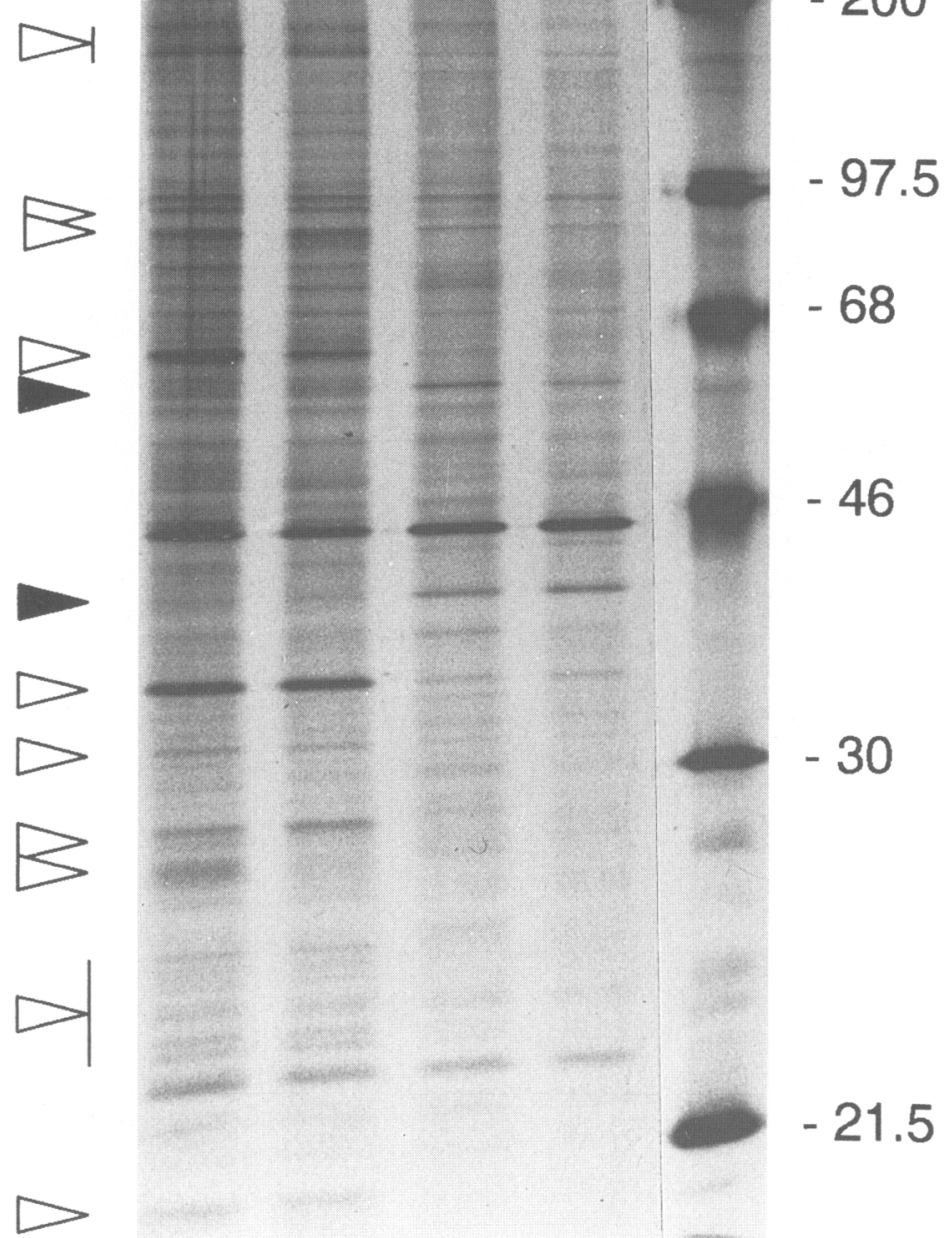

$-68$

$-46$
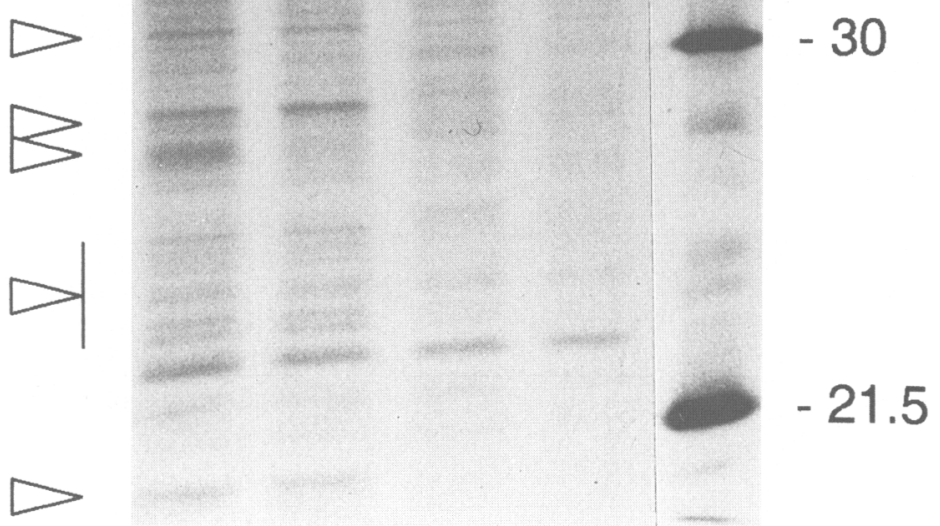

Fig. 1. Changes in the pattern of protein synthesis in maturing pig oocytes treated with the protein kinase inhibitor genistein. Oocytes were labelled with $\left[{ }^{35} \mathrm{~S}\right]$ methionine during the last $2 \mathrm{~h}$ of a $24 \mathrm{~h}$ in vitro maturation culture, to which $0,20,40$ or $60 \mu$ g genistein $\mathrm{ml}^{-1}$ was added, respectively. Polypeptides were separated on 8-15\% gradient SDS-polyacrylamide gels. Equal amounts of radioactivity were loaded per lane. Protein bands which were increased or decreased by the treatment in comparison with controls are indicated by filled or open arrowheads, respectively.

after genistein treatment $\left(40\right.$ or $60 \mu \mathrm{g} \mathrm{ml}^{-1}$ ) were significantly different from that of GV oocytes (T. Jung, J. Fulka, Jr and R. M. Moor, unpublished).

\section{Discussion}

We report that the addition of genistein, a protein kinase inhibitor, during culture of pig oocytes in vitro, inhibited oocyte maturation in a dose-dependent manner. The oocytes were sensitive to genistein for the first $12 \mathrm{~h}$ of maturation. Genistein altered, in a dose-dependent manner, not only the pattern but also decreased the amount of protein synthesis and phosphorylation to 2 and $3 \%$ of control levels, respectively, when $80 \mu \mathrm{g}$ genistein $\mathrm{ml}^{-1}$ was used. The effects of genistein $\left(80 \mu \mathrm{g} \mathrm{ml}^{-1}\right)$ were reversible and the oocytes resumed maturation after release from the arrest.

Genistein was first isolated as a weak yellow dye from the dyers broom Genista tinctoria L. in 1899. In 1951, it was described as the oestrogenic compound in subterranean (Trifolium subterraneum L.) 


\section{Genistein}

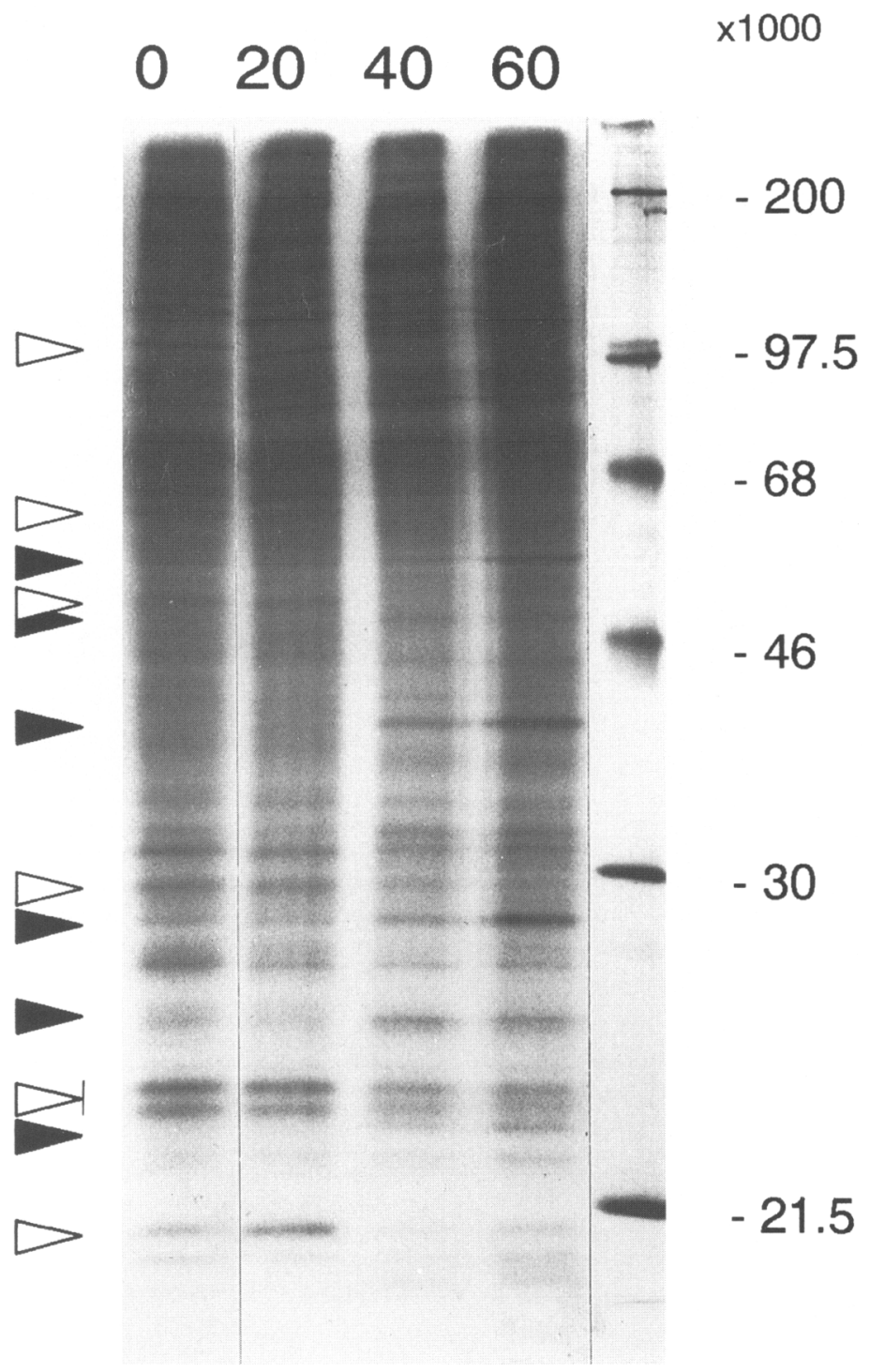

Fig. 2. Changes in the pattern of protein phosphorylation in maturing pig oocytes treated with the protein kinase inhibitor genistein. Oocytes were labelled with $\left[{ }^{32} \mathrm{P}\right]$ orthophosphate during the last $2 \mathrm{~h}$ of a $24 \mathrm{~h}$ in vitro maturation culture, to which $0,20,40$ or $60 \mu \mathrm{g}$ genistein $\mathrm{ml}^{-1}$ was added, respectively. Polypeptides were separated on $8-15 \%$ gradient SDS-polyacrylamide gels. Equal amounts of radioactivity were loaded per lane. Protein bands which were increased or decreased by the treatment in comparison with controls are indicated by filled or open arrowheads, respectively.

and other clovers (reviewed by Biggers, 1958). Later, genistein was characterized as an inhibitor of protein tyrosine kinases with inhibitor concentration $\left(\mathrm{IC}_{50}\right)$ values of $2.6-26 \mu \mathrm{mol} \mathrm{I}^{-1}$ towards the EGF receptor and $\mathrm{pp} 60^{v-s r c}$ (Akiyama et al., 1987; Akiyama and Ogawa, 1991). However, genistein is not highly specific for tyrosine protein kinases. Inhibitor concentration $\left(\mathrm{IC}_{50}\right)$ values of $15-185 \mu \mathrm{mol} \mathrm{I^{-1 }},>200 \mu \mathrm{mol} \mathrm{I}^{-1}$ and $>200 \mu \mathrm{mol} \mathrm{I}^{-1}$ towards protein kinase $\mathrm{C}$, cyclic AMPdependent protein kinase and $\mathrm{Ca}^{2+} /$ calmodulin-dependent protein kinase, respectively, were reported (Akiyama et al., 1987;
Geissler et al., 1990; O'Dell et al., 1991). In addition to tyrosine protein kinases, other protein kinases, in particular protein kinase $C$, are targets for genistein inhibition. The effective concentration $\left(E D_{50}\right)$ values for genistein in our experiments towards maturation rate, protein phosphorylation and protein synthesis were about $40 \mu \mathrm{g} \mathrm{ml}^{-1}\left(150 \mu \mathrm{mol} \mathrm{l}^{-1}\right)$ and therefore within the inhibitor concentration values for tyrosine protein kinases and protein kinase $C$. However, inhibition of protein kinase $\mathrm{C}$ and cyclic AMP-dependent protein kinase with the isoquinoline sulfonamide inhibitors $\mathrm{H} 7$ and $\mathrm{H} 8$ blocked the 
maturation of only 20 and $12 \%$, respectively, of pig oocytes in vitro. Protein synthesis patterns were unaffected by $\mathrm{H} 7$ or $\mathrm{H} 8$ treatment (Jung et al., 1992).

In one-cell stage mouse embryos, genistein had no significant effects on either uptake or incorporation of $\left[{ }^{35} \mathrm{~S}\right]$ methionine or on protein synthesis pattern. Similarly, no changes were observed in overall amounts of $\left.{ }^{32} \mathrm{P}\right]$ orthophosphate uptake and incorporation and phosphoprotein pattern after genistein treatment $\left(75 \mu \mathrm{mol} \mathrm{l}^{-1}\right)$; however, tyrosine phosphorylation was significantly decreased to about $0.5 \%$ of total phosphoamino acids (Besterman and Schultz, 1990). This was comparable to the experiments reported here in which a similar concentration of genistein $\left(20 \mu \mathrm{g} \mathrm{ml}^{-1}\right)$ had no effects on protein synthesis and overall protein phosphorylation in pig oocytes. However, higher concentrations of genistein significantly decreased both $\left[{ }^{35} \mathrm{~S}\right]$ methionine and $\left[{ }^{32} \mathrm{P}\right]$ orthophosphate incorporation and significantly changed both protein synthesis and protein phosphorylation patterns.

When genistein $\left(75 \mu \mathrm{mol} \mathrm{l^{-1 }}\right)$ was added during the GIphase of the first embryonic cell cycle in the mouse, thymidine incorporation was decreased, DNA synthesis blocked and the embryos were arrested at the one-cell stage. Treatment of mouse embryos in the G2-phase of the cell cycle had no effect on cell cycle progression. The genistein effects were fully reversible (Besterman and Schultz, 1990). Mouse oocyte maturation is inhibited by genistein in a dose-dependent manner $\left(\mathrm{ED}_{50}: 20 \mu \mathrm{g} \mathrm{ml}^{-1}\right.$ ). This effect is completely reversible (Kimura et al., 1991). A similar concentration of genistein had no effects on pig oocyte maturation in vitro. However, maturation was inhibited in a dose-dependent manner by higher concentrations of genistein $\left(E D_{50}: 40 \mu \mathrm{g} \mathrm{ml}^{-1}\right)$. Again this inhibitory effect was fully reversible. The genistein sensitive period during pig oocyte maturation was the first $12 \mathrm{~h}$, which is similar to the cycloheximide sensitive period (Fulka et al., 1986; Kubelka et al., 1988). Concentrations of genistein that inhibit pig oocyte maturation also decrease protein synthesis and overall protein phosphorylation with a similar dose-response relationship $\left(\mathrm{ED}_{50}: 40 \mu \mathrm{g} \mathrm{m}^{-1}\right)$. The drug effects cannot therefore be solely addressed by the inhibition of protein phosphorylation. However, in contrast to inhibition of oocyte maturation with cycloheximide, which blocks GVBD but not chromatin condensation, genistein inhibited both events.

In the mouse fibroblast cell line $\mathrm{NIH}-3 \mathrm{~T} 3$, genistein has a cytostatic effect at $40 \mu \mathrm{mol} \mathrm{l}^{-1}$ and could block the mitogenic activity mediated by EGF and insulin. In addition, genistein in these cells inhibits a mitogen-stimulated S6 kinase at $15 \mu \mathrm{mol} \mathrm{l}^{-1}$ (Linasier et al., 1990). The phosphorylation of the S6 ribosomal protein by S6 kinases upregulates protein synthesis (Smith et al., 1980; Palen and Traugh, 1987). A kinase cascade that activates S6 kinase II involves MAP 2 kinase and MPF. MAP kinase and $\mathrm{p} 34^{\text {cdc } 2}$, which is the catalytic subunit of the MPF, are tyrosine phosphorylated proteins. However, p $34^{\text {cdc2 }}$ becomes activated by tyrosine dephosphorylation which induces activation of MAP kinase by an indirect pathway. Activated MAP 2 kinase is tyrosine phosphorylated (Gotoh et al., 1991; Matsuda et al., 1992). MAP 2 kinase is a direct activator of S6 kinase II (Sturgill et al., 1988). The direct or indirect effects of genistein on S6 phosphorylation could explain the effects of genistein on protein synthesis in pig oocytes.
In summary, genistein inhibits oocyte maturation in pigs in a reversible manner. This inhibitory effect is accompanied by inhibition of protein synthesis and total protein phosphorylation. The effective concentration $\left(\mathrm{ED}_{50}\right.$ ) values of genistein in the pig experiments were in the range of inhibition of tyrosine protein kinases and protein kinase C. Future experiments should identify which protein phosphorylation and protein synthesis steps are involved in the regulation of chromatin condensation and nuclear membrane breakdown during maturation of pig oocytes.

T. Jung was supported by a Deutsche Forschungsgemeinschaft Fellowship (Ju 193/1-1, Ju 193/1-2) and J. Fulka, Jr by MHPR-CR (No. 503) and BEMA.

\section{References}

Akiyama $\mathrm{T}$ and Ogawa $\mathrm{H}$ (1991) Use and specificity of genistein as inhibitor of protein-tyrosine kinases Methods in Enzymology 201 362-370

Akiyama T, Ishida J, Nakagawa S, Ogawara H, Watanabe S, Itoh N, Shibuya M and Fukami $Y(1987)$ Genistein, a specific inhibitor of tyrosine-specific protein kinases Journal of Biological Chemistry $2625592-5595$

Besterman B and Schultz RM (1990) Regulation of mouse preimplantation development: inhibitory effect of genistein, an inhibitor of tyrosine protein phosphorylation, on cleavage of one-cell embryos Joumal of Experimental Zoology $25644-53$

Biggers JD (1958) Plant phenols possessing oestrogenic activity. In The Pharmacology of Plant Phenolics, pp 51-69. Academic Press, London

Doree M (1990) Control of M-phase by maturation-promoting factor Current Opinion in Cell Biology 2 269-273

Fulka J Jr, Motlik J, Fulka J and Jilek F (1986) Effect of cycloheximide on nuclear maturation of pig and mouse oocytes Journal of Reproduction and Fertility 77 $28 \mathrm{I}-285$

Geissler JF, Traxler P, Regenass U, Murray BJ, Roesel JL, Meyer T, McGlynn E, Storni A and Lydon NB (1990) Thiazolidine-diones, biochemical and biological activity of a novel class of tyrosine protein kinase inhibitors journal of Biological Chemistry 26522 255-22 261

Gotoh Y, Moriyama K, Matsuda S, Okamura E, Kishimoto T, Kawasaki H, Suzuki K, Yakara I, Sakai H and Nishida E (1991) Xenopus M-phase MAP kinase: isolation of its CDNA and activation by MPF EMBO journal 10 2661-2668

Jung T, Lee C and Moor RM (1992) Effects of protein kinase inhibitors on pig oocyte maturation in vitro Reproduction, Nutrition, Development 32 461-473

Kimura H, Endo Y, Fukuyama R, Oba M, Shimizu N, Suzuki S and Nozawa S (1991) Inhibitory effect of genistein on mouse oocyte maturation Human Reproduction 6 (Supplement 1) 121-122

Kubelka M, Motlik J, Fulka J Jr, Prochazka R, Rimkevicova Z and Fulka J (1988) Time sequence of germinal vesicle breakdown in pig oocytes after cycloheximide and p-aminobenzamidine block Gamete Research 19 423-431

Laemmli U (1970) Cleavage of structural proteins during the assembly of the head of bacteriophage T4 Nature $227680-685$

Linasier C, Pierre M, Le Pecq J-B and Pierre J (1990) Mechanism of action in NIH-3T3 cells of genistein, an inhibitor of EGF receptor tyrosine kinase activity Biochemical Pharmacology 39 187-193

Maller IL (1990) Xenopus oocytes and the biochemistry of cell division Biochemistry $293157-3166$

Matsuda S, Kosako H, Takenaka K, Moriyama K, Sakai H, Akiyama T, Gotoh Y and Nishida E (1992) Xenopus MAP kinase activator: identification and function as a key intermediate in the phosphorylation cascade EMBO Journal 11 973-982

Morton HJ (1970) A survey of commercially available tissue culture media In vitro $689-108$

Motlik J and Fulka J (1976) Breakdown of the germinal vesicle in pig oocytes in vivo and in vitro Joumal of Experimental Zoology 198 155-162

Norbury C and Nurse P (1992) Animal cell cycles and their control Annual Reviews in Biochemistry $61441-470$

Nurse P (1990) Universal control mechanism regulating onset of M-phase Nature 344 503-508 
O'Dell TJ, Kandel ER and Grant SGN (1991) Long term potentiation in the hippocampus is blocked by tyrosine kinase inhibitors Nature 353 558-560

Palen E and Traugh JA (1987) Phosphorylation of ribosomal protein S6 by cAMP-dependent protein kinase and mitogen-stimulated S6 kinase differentially alters translation of globin mRNA Journal of Biological Chemistry 262 3518-3523

Ray LB and Sturgill TW (1987) Rapid stimulation by insulin of a serine/ threonine kinase in 3T3-LI adipocytes that phosphorylates microtubulesassociated protein 2 in vitro Proceedings of the National Academy of Sciences USA 84 1502-1506
Ray LB and Sturgill TW (1988) Insulin-stimulated microtubule-associated protein kinase is phosphorylated on tyrosine and threonine residues in vivo Proceedings of the National Academy of Sciences USA 85 3753-3757

Smith CJ, Rubin CS and Rose, OM (1980) Insulin-treated 3T3-L1 adipocytes and cell-free extracts derived from them incorporate ${ }^{32} \mathrm{P}$ into ribosomal protein $\mathrm{S} 6$ Proceedings of the National Academy of Sciences USA 77 2641-2645

Sturgill TW, Ray LB, Erickson E and Maller JL (1988) Insulin-stimulated MAP-2 kinase phosphorylates and activates ribosomal protein S6 kinase II Nature $334715-718$

Yarden Y and Ullrich A (1988) Growth factor receptor tyrosine kinases Annual Reviews in Biochemistry 57 443-478 